\title{
THE POTTER BOX MODEL OF MORAL REASONING
}

\section{El modelo Potter box de razonamiento moral}

\author{
Miguel Franquet-Santos-Silva and Carlos-Aurélio Ventura-Morujão
}

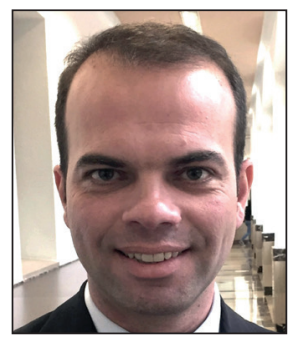

Miguel Franquet-Santos-Silva holds a master's in contemporary philosophy from the Catholic University of Portugal and a PhD in journalism from the Ramon Llull University (URL), Barcelona. His thesis topic was ethics and photojournalism; his PhD dissertation was awarded the "Premio extraordinario de doctorado of the URL" in 2015-16. He is a lecturer at the Department of Communication Studies at the Faculty of Social Sciences of the Abat Oliba University (UAO) and at the Department of Humanities of the Faculty of Communication and International Relations at the URL. Between 2013 and 2015 he was a visiting scholar in the Journalism Department of the University of Sheffield. His teaching and research activities are focused on media ethics, theory of communication, and contemporary philosophy. He is a member of the editorial board of the Journal of applied journalism and media studies, and head of the International Office at the UAO. http://orcid.org/0000-0002-3940-2619

Universitat Abat Oliba CEU Bellesguard, 30, 08022 Barcelona, Spain mfranquetd@uao.es

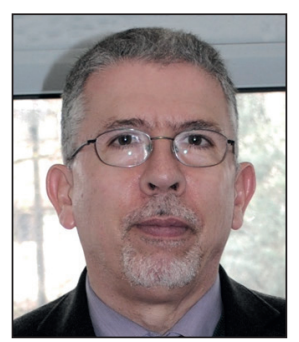

Carlos-Aurélio Ventura-Morujão is full professor with the Faculty of Human Sciences of the Portuguese Catholic University, and director of the research \& development unit Center of Philosophical Studies. He teaches History of modern philosophy, History of contemporary philosophy, and Anthropology. His main area of interest is Husserl's phenomenology, about which he has lectured and written extensively in the last 15 years. In 2015 he published his most recent book, Caminhos da fenomenologia. His research also addresses the relationship between phenomenology and the social sciences, and phenomenology and psychoanalysis. He has had papers published in several philosophical journals in Spain, Brazil, and the United States, and book chapters in Spain, France, and Germany.

http://orcid.org/0000-0001-9943-8229

Faculdade de Ciências Humanas Palma de Cima, 1649-023 Lisboa, Portugal carlosmorujao@fch.lisboa.ucp.pt

\begin{abstract}
This article questions the effectiveness of the Potter box model of moral reasoning when applied to information ethical dilemmas. Though its importance in feeding the desirable rational debate on ethical problems, this model, and probably all models, fails in the most problematic cases to solve the question of which theory best fits to a particular situation. With the help of some examples provided in Media ethics: Cases and moral reasoning (Christians et al., 2005), we will seek to demonstrate that ultimately decisions are grounded in what Paul Ricoeur calls "conviction". No solutions to ethical dilemmas can be found a priori. That is the drama of action.
\end{abstract}

\section{Keywords}

Media ethics; Moral reasoning; Potter box; Drama; Communication ethics; Aristotle; Kant; Ricoeur; Conviction.

\section{Resumen}

El artículo cuestiona la efectividad del modelo de razonamiento ético de la Potter box en cuanto a su aplicación a dilemas de ética de la información. No obstante su importancia para fomentar el debate racional sobre ética aplicada, este modelo, como probablemente todos los modelos de razonamiento ético, es incapaz de determinar la teoría moral que mejor podría justificar el curso de acción justo en los casos más dilemáticos. A partir de varios ejemplos presentados en Media ethics: Cases and moral reasoning (Christians et al., 2005), mostraremos que las decisiones morales, en última instancia, radican en lo que Paul Ricoeur llama "convicción". Ninguna solución para dilemas éticos puede ser encontrada a priori. Ese es el drama de la acción.

\section{Palabras clave}

Ética de la comunicación; Razonamiento ético; Potter box; Aristóteles; Kant; Ricoeur; Convicción. 
Franquet-Santos-Silva, Miguel; Ventura-Morujão, Carlos-Aurélio (2017). "The Potter box model of moral reasoning". EI profesional de la información, v. 26, n. 2, pp. 328-335.

https://doi.org/10.3145/epi.2017.mar.20

\section{Introduction}

While not commonly discussed among the European ethics and ethics of information research communities, the model of moral reasoning proposed by Ralph B. Potter, known as the Potter box ${ }^{1}$, has enjoyed strong influence in the United States across various fields such as journalism, public relations, advertising, and business ethics, especially since the publication, in 1983, of Media ethics: Cases and moral reasoning (Christians; Rotzoll; Fackler, 1983). The publication of its $10^{\text {th }}$ edition in 2016 constitutes a good opportunity to revise the ethical model and reassess its effectiveness.

According to its authors, the Potter box can operate as a valuable framework for applied ethical reasoning processes and serves to feed the rational debate and critical analysis that is so often lacking when taking decisions bearing ethical implications. According to this model, the decision-making framework, when faced with moral dilemmas should be divided into four major steps:

- description of the situation;

- identification of the values held by the individuals involved;

- prescriptions of ethical principles adjusted to the situation;

- definition of loyalties and responsibilities.

The purpose of this paper is to reflect on applications of the

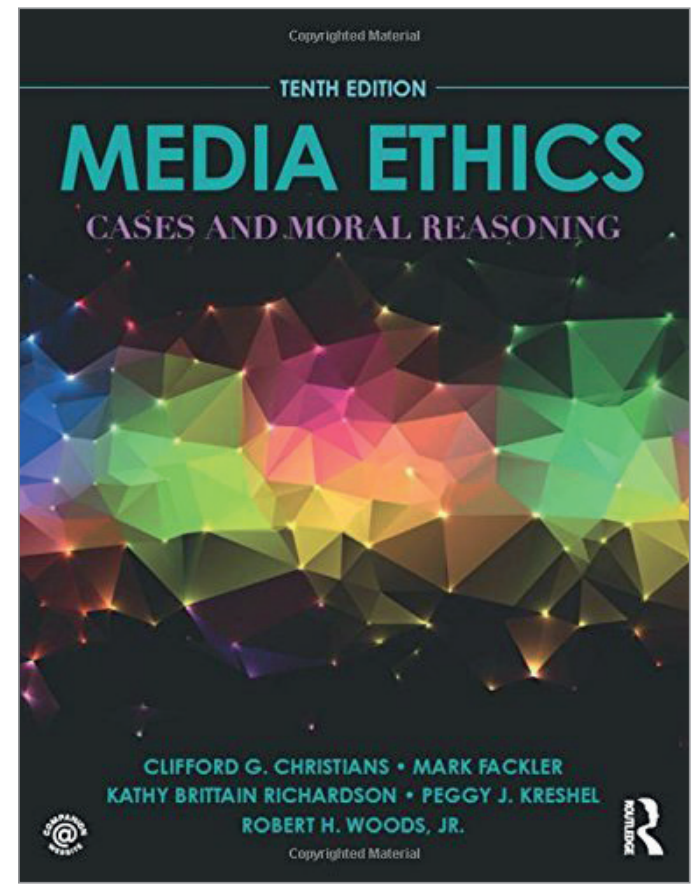

Christians, Clifford G.; Fackler, Mark; Richardson, Kathy-Brittain; Kreshel, Peggy J.; Woods, Robert H. (2016). Media ethics: Cases and moral reasoning (10 ${ }^{\text {th }}$ ed.). New York: Routledge, 405 pp. ISBN 978120589774
Potter box model to information problems and evaluate its effectiveness. With the help of case studies provided in the book, we seek to demonstrate that, despite its merits in contributing to the media ethics debate, the Potter box fails to solve the problem of which of the major ethical theories to apply in each concrete situation.

\section{The Potter box model of moral reasoning}

According to Christians et al., the Potter box can be understood as a technique for revealing the important steps in moral deliberation in order to ground and justify practical decisions. Correspondingly, the model is based on the assumption that moral judgments must be rational, i.e. based on valid arguments. However, this does not mean that the model provides unique and unquestionable solutions to the problems presented. Its purpose is primarily to foster rational discussion that takes into account the identification of values, the choice of a theoretical framework, and the definition of responsibilities of those involved. Its application to the scope of ethical reflection has two objectives:

- to develop analytical skills;

- to promote the moral conscience of subjects (Christians et al., 2005).

The Potter box advocates the division of ethical reflection into four main steps: two seek to generate the relevant information, and the latter two are normative or prescriptive

The Potter box advocates the division of ethical reflection into four main steps: the first two are descriptive and seek to generate the relevant information for subsequent discussion and decision-making, and the latter two are normative or prescriptive. This model works as a system by which each of the four dimensions or steps is mutually interlinked.

- First, a description of the specific situation under analysis should be carried out.

The authors call this the moment of empirical definition.

- In the second stage, the identification of values held by the agents is set out.

It should be noted that this second step should only be considered descriptive when analysis focuses on a past event, i.e. when our aim is the reconstruction of the motives that made an agent act in a certain way. If we apply the model to a current situation requiring a decision, the nomination of values deemed appropriate corresponds to a prescriptive moment. Hence, a journalist may decide that in certain situations the privacy of individuals should be respected 
1. Description of the situation

2. Identification of values
4. Definition of loyalties and responsibilities

\section{Choosing the principles}

Figure 1. The Potter box

and prevail over the public's right to information. Among the values identified by the authors, it is worth pointing out the aesthetic (harmony, order, symmetry, etc.), the logical (consistency, competence, etc.), the professional (proximity, innovation, impact, conflict, human interest, etc.) and the moral values (truth, respect for human dignity, honesty, etc.). The listing of these value types explains why the Potter box model may be applied not only to journalism and advertising, but also to public relations and entertainment. While it is true that distinct professional values are present in each of these activities, there is no doubt that nowadays the distinction between the fields of advertising, entertainment, and information is tending to blur. This contamination is at the basis of a set of phenomena such as «infotainment» or «branded content». In the former, information is mixed up with entertainment to create a hybrid genre that undermines the credibility of information and jeopardizes its seriousness. In the latter case, information is mixed into advertising, thereby eradicating core journalistic values such as impartiality and objectivity.

Beyond this misappropriation of professional values for other activities, there are distinct and legitimate values that can compete with each other in decision-making. The aforementioned example, in the case of journalism, is paradigmatic: in some situations, it is not easy to decide whether a particular piece of information meets the requirements that endow it with the status of public interest; the main criterion enabling the imposition of the public's right to information and overriding respect for the privacy of those involved. That happens in one of the cases analyzed in the book and to which we shall return later.

- The third step may be considered fundamental. It is the critical moment at which media practitioners choose the principles of the ethical doctrine that grounds their position.

According to the authors, "no conclusion can be morally justified without a clear demonstration that an ethical principle orientated the final decision" (Christians; Rotzoll; Fackler, 2005 , p. 10). It is therefore not enough, as often happens, to justify the action based on a set of values. We must submit them to critical reflection in order to determine and assess the end by which they are evaluated as good.

The importance of this critical assessment of values becomes more evident if we concur with the authors that "professional values are inscribed in power" (Christians et al., 2005, p. 10) and that many statements of good intentions conceal particular interests, guided by a logic totally unrelated to the pursuit of good information. It is, therefore, important to pay attention to those speeches with ethical implications made by decision makers to discover, in the rhetoric deployed, which values fundamentally underpin and support the decisions taken, which is often unclear. Boris Libois also reminds us of this problem in calling for an instrumental use of ethics. At a time of great profusion of moral discourses, it is important to recall that, very often, those speeches do not commit their orators to the achievement of the good of each activity, but have only personal, political, or commercial purposes (Libois, 1994, p. 7 and ff.).

Following the division of ethical theories into five major categories (virtue, duty, utility, rights, and love), as proposed by Louis Hodges, the authors suggest that the justification for our decisions should be based on one of the following:

1) Aristotle's Mean according to which "moral virtue is a middle state determined by practical wisdom".

2) Kant's categorical imperative: "Act only on that maxim through which you can at the same time will that it should become a universal law [of nature]";

3) the principle of utility of Stuart Mill: "Seek the greatest happiness for the greatest number";

4) John Rawls' veil of ignorance: "Justice emerges when socially negotiating without social differentiations";

5) the Judeo-Christian point of view of the person as an end: "Love your neighbor as yourself".

\section{A journalist may decide that in certain situations, the privacy of individuals should be respected and prevail over the public's right to information}

Each of these five categories raises important problems that a philosophical reflection on ethical issues has already acknowledged. It's not easy, even from the Aristotelian viewpoint, to define practical wisdom, since complex situations can make the wisest man make the wrong decision; Kant's categorical imperative doesn't seem to suffice in exceptional situations when it is difficult to guarantee the universality of a maxim; even the greatest happiness, in Mill's sense, can become problematic in the case of a conflict between contending notions of individual or social happiness; Rawls' veil of ignorance can fail when individuals engaged in a negotiation are unsuccessful at reckoning the social prejudices that may underlie their arguments; and an ethics based on love sometimes demands to much from people that don't love each other but are anyway obliged to conform their mutual behaviors with the principles of fairness and justice.

Despite the importance granted to an act of reasoning 
relying on ethical principles developed by one of the major moral concepts, the authors do not hesitate to state that "(...) no one theory can satisfactorily resolve all ethical questions and dilemmas in media ethics"; so it is important to understand which theory best fits each specific situation and encourage each to think for themselves with "rebellion or amiably, as circumstances demand it" (Christians et al., 2005, pp. 11-12).

- Finally, we have the fourth step, which corresponds to the definition of loyalties and responsibilities. To whom should we respond and justify the decisions taken?

The authors identify five categories of obligations:

- towards our own conscience;

- towards customers and subscribers;

- towards the organization;

- towards professional colleagues;

- towards society.

In defending social ethics, inherited from the theory of social responsibility, the authors state that obligations towards society assume great importance. Although this school, heir to the work done by the Hutchins Commission, insists on the idea that ethics for the media is not limited to ethics for journalists, and that they imply the responsibility of the media as organizations, which might lead to the dissolution of individual responsibility, the authors firmly state that "ultimate responsibility finally rests on individuals" (Christians et al., 2005, p. 25).

As is the case with the third step, the fourth may prove decisive when legitimate, but differing values compete to guide the same outcome. Furthermore, the need to define loyalties has another objective. According to the authors, the importance of this final stage is also justified by the importance given to the establishment of a concrete link between the model and life, which requires considering the implications and consequences of decisions taken.

After this brief presentation of the Potter box, it is important to detail how the model can actually be used. Referring to some examples provided in the book, we hereby seek to evaluate the effectiveness of the model and re-

flect on some of its assumptions.

\section{The limits of the Potter box model}

The first case the book examines focuses on a shocking crime, which occurred on 12 February 1993, in Liverpool, where two minors of age, only ten years old, Robert Thompson and Jon Venables, abducted and violently killed James Bulger, only two years old (Christians; Rotzoll; Fackler, 2005, p. 25). According to the English legal system, children under ten years may be criminally charged but any disclosure of information about the family or the identity of those involved is forbidden until the case is closed. Beyond this legal imposition, there was another when, in 2001, the pair was released and the court ruled that both their new identities along with any other information that might contribute towards their identification should not be revealed. The question that arises is that of two attitudes towards this injunction, which, from a legal point of view, concerns only the British media. In this context, the authors suggest we analyze two opposite attitudes: the attitude of a British television channel, which acts in accordance with the law of its country, and that of a North American newspaper, which decides to focus on the right of the public to information.

If we take into account professional values, we could say that both decisions are defensible. As a matter of fact, the television station attitude is justified as any disclosure of information about the case would, first, increase the pain of relatives of the murdered children as well as hinder the possible and desirable reintegration and rehabilitation of the minors who had committed the crime. This is also the reason many codes of journalist ethics recommend not mentioning the names of children involved in violent crimes. But the American newspaper position is also defensible as far as it defends the public's right to information. In this case, what would be affected would not be the re-running of morbid aspects to the tragedy, but instead the disclosure of information about the family situation of the children in order to help the public better understand what happened. Furthermore, it can be argued that each position is justified based on ethically legitimate principles. The British television position would be justified under the principle of Christian love of fellow humans, trying to safeguard the Bulger's family pain and the American newspaper position justified by the Kantian ethics requiring that truth must always be told.

Nevertheless, it's questionable that truth must be told in every circumstance, if by truth we just mean saying what happened exactly as it happened, when and where it happened. For instance, if in a dictatorship a political activist is arrested by the police and is asked where his fellow activists are hidden, he is not obliged to say the truth to the police. Here the solution to the problem is very simple and Kant would agree with it. A man is only juridically compelled to say the truth in a situation where he or his representatives have been able to participate in the establishment of the laws (Kant, 1998, p. 640), which is not the case in a dicta-

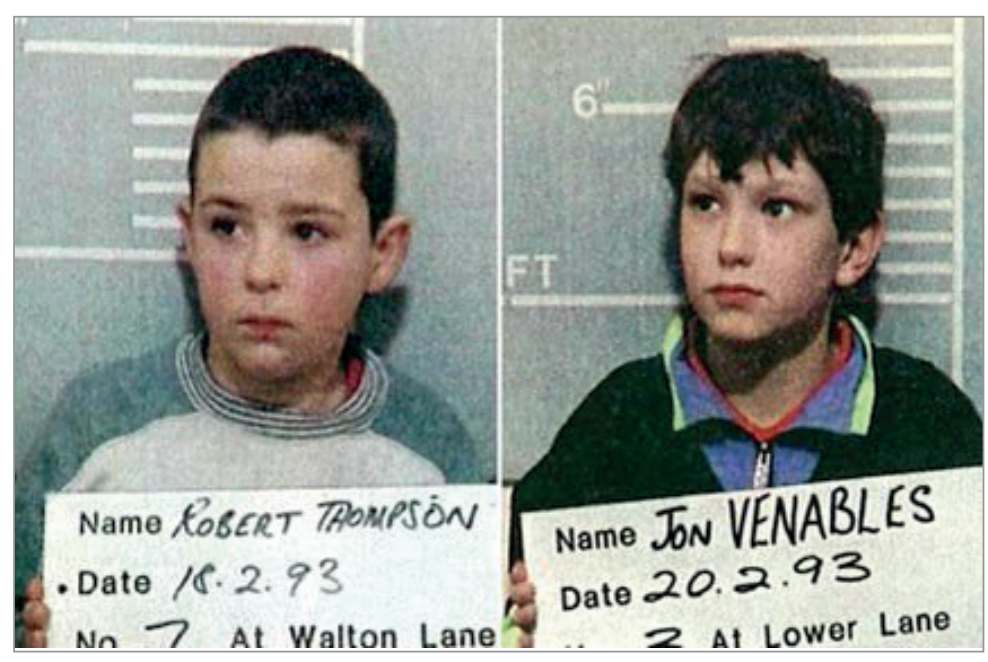

https://theukdatabase.com 
torship. A more difficult case happens when we think of a journalist being compelled -for instance, in a court of justice- to reveal the circumstances in which he has interviewed someone who is being persecuted by the police. Perhaps there are no absolute answers to this question. The two extreme and opposite solutions to this dilemma would be:

- A journalist can never reveal his sources, or else he undermines by his behavior the ethical commitment he assumed with his source that enabled him to be a source, i.e. the guarantee he offered that the source would remain unknown.

- A journalist must always decide, by his own initiative, under what circumstances the commitment he assumed can be broken.

Under the rule of law a journalist is only committed to reveal his sources under the circumstances this same law determines he must do so

The only reasonable solution, under the rule of law, seems to be that a journalist is only committed to reveal his sources under the circumstances this same law determines he must do so. Perhaps this solution will sometimes create conflicts between deontological and ethical codes and the laws of some countries. But there is no ethical code or any system of law that can provide an answer to every situation. There may be exceptional circumstances -that no code nor law, even the most perfect ones, can forsee- in which the journalist can only trust his own personal decision (of course we are dealing with cases in which the journalist takes seriously his job and the commitments he has taken with his sources, his readers and his fellow journalists; in cases of lack of will to remain faithful to them, any decision can be expected.) now is, to whom should journalists feel responsible? The authors are categorical: towards the innocent victims of this tragedy.

The second case selected for analysis dates back to April 11, 2003, when Eason Jordan, a CNN chief executive, published in The New York Times a controversial article entitled "The news we kept to ourselves» (Jordan, 2003), in which it was stated that $C N N$ had not published many of the atrocities committed by the Saddam Hussein regime to avoid its employees, officials, and information sources suffering serious reprisals from the Iraqi regime. In this article Eason Jordan tells, for example, how in the mid-90s one of his cameramen in Iraq was kidnapped and tortured by the Iraqi secret police as he would not confirm that he, Eason Jordan, was the Baghdad CIA director: "CNN has been in Baghdad long enough to know that telling the world about the torture of one of its employees would almost certainly have got him killed" (Christians et al., 2005, p. 39). He also says that CNN could not disclose information that the eldest son of Saddam, Uday, had revealed because it would endanger the life of an Iraqi translator who had witnessed the conversation between them. He ends by confessing a deep malaise for not having been able to denounce these and other stories that testify to the terror of the victims of the finally toppled regime.

Criticism of the controversial article by Eason Jordan appeared immediately. Many peers criticized CNN's position arguing that the station's credibility had been deeply affected and that nobody could thereafter trust its reporters sent to other countries such as China, Cuba, Sudan, or Syria. Furthermore, others argued that good information is not compatible with the concessions made to the Saddam Hussein regime and that, in the circumstances described by Eason Jordan, it would have been better not to report any information rather than misleading coverage. Bob Steele, director

Alerted by the possibility of an instrumental use of ethics, we must inquire whether, in the above-mentioned case, it is not the fear of legal sanction imposed for breach of the injunction (for the British television station) and the desire to respond to the wishes and curiosity of readers (in the case of the American newspaper) that actually ground the positions taken.

As the critique to which values have been subject during the third step shows, both editorial decisions have the support of ethically justifiable principles. In this context, the model requires loyalties be investigated. In abstract terms, both positions are defensible with each contributing in their own way towards achieving good information. Nevertheless, we have just seen that this is simply not enough. The question that arises

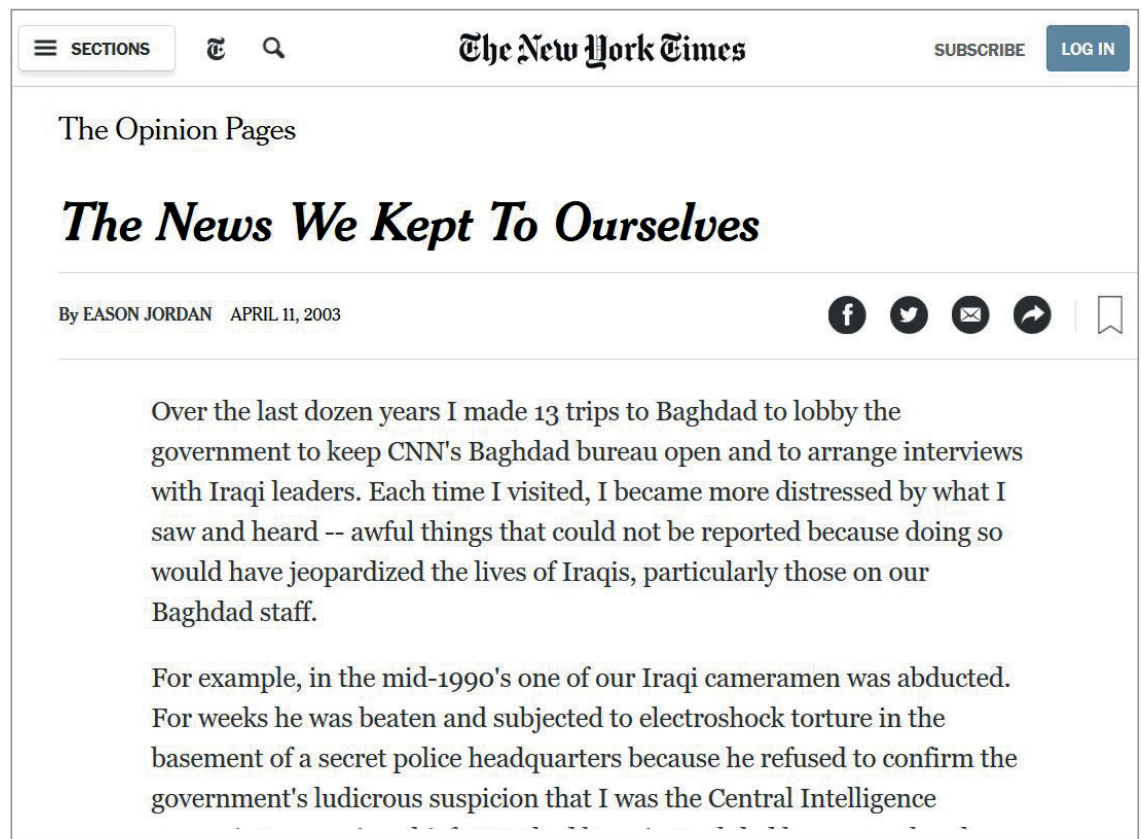

http://www.nytimes.com/2003/04/11/opinion/the-news-we-kept-to-ourselves.html 
of the Poynter Institute ethics program, considers that the question cannot be faced so unilaterally. He says that the majority of the criticism did not take into consideration the complexity of the issue and even discouraged other mass media outlets from declaring the compromises that they had also been subject to in Iraq (Steele, 2003).

In such complex cases, which involves the commitment of the media to the safety of their employees on the one hand, and to the truth of information, on the other, the authors of Media ethics recommend taking into account the Aristotelian principle of temperance (Aristotle, 1985, p. 47), thought of as an individual virtue that regulates the soul's appetites in accordance with "fair-measure». Although the authors' position is not as categorical as in the previous case, they suggest that the best decision here should have been that of leaving Baghdad and pursuing rigorous information from outside (Christians et al., 2005, p. 41).

\section{Publishing graphic pictures of suffering and death is only justified when there is an "overriding public interest" at stake}

Within the context of the Potter box, moral principles and ethical theories (quadrant three) are expected to play a critical role in ethical decision-making processes. According to the authors, applying values (quadrant two) does not guarantee that ethical decisions are morally justified. Valuing, the authors state, "automatically come to expression in everyday circumstances" (Christians et al., 2005, p. 10). Without much thinking, people would decide according to community mores. Moreover, "values are never pure" and "professional values are inscribed in power" (ibidem). It could be argued, for instance, that, as a general rule, withholding graphic pictures of suffering and death is a moral imperative, and that publishing them is only justified when there is an "overriding public interest" at stake and when seeing those pictures does change significantly people's knowledge and attitudes regarding news events. But as we suggested before, there are good reasons to believe that abusive interpretations of the concept of "public interest" have been used to justify withholding important visual information. In this regard, the coverage of the "war on terror" operation, which began in the aftermath of 9/11, offers a welldocumented case study (Butler, 2004; Bennett; Lawrence; Livingstone, 2007; Zelizer, 2010). In About to die: How news images move the public, Barbie Zelizer showed that editorial decisions undertaken by American news media to suppress pictures of dead bodies were not necessarily motivated by ethical concerns, but by a complex set of instrumental reasons (Zelizer, 2010). Centring the analysis on three different events - the killing of Taliban soldiers by beating in 2001, the beheadings of journalists Daniel Pearl and Nick Berg in 2002 and 2004, and the hanging of Saddam Hussein in 2006-, Zelizer contends that the decision to publish pictures of their impending deaths instead of pictures of their dead bodies helped American newspapers to attain three different strategic goals: first, to protect themselves against accusations of immorally taking advantage of people's death; second, to accommodate their report to different interpretations of death caused by war, maintaining a sort of equidistant position that intended to reinforce their authority; and third, because pictures of people-about-to-die depict unsettled events, which requires the public to be an active participant in order to complete the missing information, these pictures end up increasing people's engagement with the news.

To overcome these "sociological matters", authors recommend stepping to quadrant three where ethical deliberation is due to identify "which theory is the most powerful under what conditions" (Christians et al., 2005, p. 11). Besides recognizing the difficulties involved in identifying which theory best matches a particular situation, authors underline another major issue, concerned with people's willingness to act morally and to abide by other patterns of ethical reasoning. However, the Potter box model could not address this major difficulty. But, there is another relevant issue involved in the process of finding the "right theory" that the authors do not seem to give due importance. While ascribing quadrant three and quadrant four a critical role, the authors do not draw students and media practitioners' attention to the fact that it would be impossible to completely get rid of the influence of those "sociological matters". Following Edmund Husserl and Alfred Schütz, it should be mentioned that together with community mores, religious beliefs, cultural and social traditions etc., these "sociological matters" configure our life-world - Husserl's Lebenswelt (Husserl, 1956, pp. 123 and ff.) -, understood as the fundamental ground upon which all human activity rests on ${ }^{2}$. Both the process of choosing the right ethical theory and the definition of loyalties are constrained by a set of individual and social shared convictions that shape our life-world. In this sense, bearing in mind that choosing the adequate moral theory and defining loyalties may also be "inscribed in power", one has to ask why they are given a privileged critical function. For instance, how could we be sure that, in the case of the Liverpool murderer, appealing to Christian love instead of appealing to Kantian ethics was not a previously defined means to an end (protecting the suffering of the Bulger's family)? And how could we be sure that the decision to withhold pictures of American dead soldiers involved in the war on terror, although eventually supported by Christian love, was not actually motivated by a complex set of instrumental factors? (Zelizer, 2010).

Of course it would be silly to claim that journalists, like other human beings in a situation requiring a moral decision, can at the same time act according to moral principles and reflect about the value of those principles guiding their action. Every man acts, in the first place, according to a background of convictions more or less established that he learned through education and inherited from the social and cultural environment. Those inherited convictions sometimes play a great role when it comes to personal convictions about what we shall not do in any circumstance. Nevertheless, men are also capable of modifying their moral convictions or adjusting them to provide the right answer to new and unexpected situations. But there are critical situations, where our stock of moral values seems to fail or to be inca- 
pable of helping us in giving the right answers. Those are the moments in which we feel that there is a responsibility that no one but ourselves can assume. That's why an ethical decision and the action that follows it is not like any other event in the world, for which we can search for a natural cause. That's also why a moral principle cannot be the immediate cause of a behavior ${ }^{3}$ : we are not in the presence of physical events but of social actors that are ethically committed, actors that try to understand, as rational beings, the situation in which they are forced to act and to grasp the possible consequences of their acts.

Whenever the application of rules to concrete situations creates conflicts, Paul Ricoeur calls for a return to ethical intentionality ${ }^{4}$. According to Ricoeur, the fact that it is not possible to simultaneously serve all values leads to the "tragedy of the action», which demands an Aristotelian "practical wisdom», linked to "moral judgment according to the situation» by which "the conviction is more decisive than the rule itself» (Ricoeur, 1991, p. 256).

\section{Ricoeur stresses the fact that norms have to be mediated by an individual's moral judgment in order to become effective}

Ricoeur's ethics of conviction can't offer the same ultimate grounds for action as Kant's moral philosophy. But, Kantian categorical imperative resists the proof of the facts -we think that's what Kant means when he says that it is universal- only because Kant was willing to pay a high price for this universality: the categorical imperative had also to be abstract -or formal, in Kant's terminology- in order to keep its validity in any possible context and for every rational being (we should never forget that Kant doesn't say "human" but "rational". Even an angel would have to act according to the imperative if he was to act morally). We see two different problems here. First: anyone can easily deduce, from Kant's categorical imperative, what he must do in a typical situation; but such a deduction may be much harder to make in other situations that are not so typical and nothing seems to warrant that such a deduction can be made at all in these cases. But the real problem seems to lie elsewhere, and we come to our second problem: moral knowledge, for Kant -as Habermas has correctly stressed (Habermas, 2014, p. 333)-, can never be the cause of voluntary moral actions, although in some cases moral knowledge can be the cause of our sense of guilt, because we have not done what we ought to have done. Kant even says that it is possible to imagine a situation in which every man acknowledges the validity of moral principles but no one acts according to them.

Ricoeur's moral philosophy tries to overcome these two problems. Against Kant, who believed that reason could become practical and impose its norms to free individuals engaged in moral action, Ricoeur stresses the fact that norms have to be mediated by an individual's moral judgment in order to become effective. We believe that it is precisely this reference to conscience and to conviction that marks the limit of both the Potter box and probably of all models of ethical reflection.

\section{Conclusion}

In the first case we analyzed, the dispute revolved around which doctrine and moral principles best fitted the actual situation. The authors suggested an answer. How was it generated? We saw how important the definition of loyalty to solve this conflict was. In the example stated, the correct decision required the victims be protected. We insist: what is the basis of this final decision? How was this conclusion achieved? Should the model not have served to justify another possibility? If so, as seems to be the case, we may have to recognize that the solution found, although consensual to a greater or lesser extent, was based on individual and social shared convictions.

In the second case examined, the authors suggested referring to the Aristotelian principle of temperance, but what does this mean? How can this be translated into practice? A solution was again presented: leave Baghdad to avoid putting employees and sources at risk and report from outside. And we ask again: what was the contribution of the model to taking this position? Will this decision necessarily result from applying the model to the case? We do not believe this to be so.

In an era marked by a crisis in metaphysical and ontological foundations, are we condemned to ethical relativism? Are all decisions equal? For those who believe they are not, which include the authors of this book, the only way seems to be the promotion of a dialogue able to establish a «certain order of priorities", which will "never refer to an irrefutable conviction and be valid for all men and for all time" (Ricoeur, 1991, p. 270).

It is precisely in doubtful cases when we must decide where to apply those principles and ethical theories that are best suited to specific situations, and the Potter box model falls silent and points beyond him

Despite the added value of this model, from which we cannot naturally expect more than a support for the moral conscience, since morality is the scope of freedom, refractory to all applications of rigorous mathematical methods, we must recognize that it is precisely in doubtful cases when we must decide where to apply those principles and ethical theories that are best suited to specific situations, that the model falls silent and "points beyond him". This is not an implicit criticism of the model, but instead due praise for its recognition of its own limits. Forcing thought to follow a unique model would imprison it, and in case of action, open the door to violence. 


\section{Notes}

1. Potter box is the name given to the model of decision-making proposed by Dr. Ralph B. Potter, professor of the Harvard Divinity School, in his 1956 Ph.D. diss. The structure of certain American Christian responses to the nuclear dilemma.

2. In Ethical theory in a global setting Christians addresses this question when referring to the Habermas-

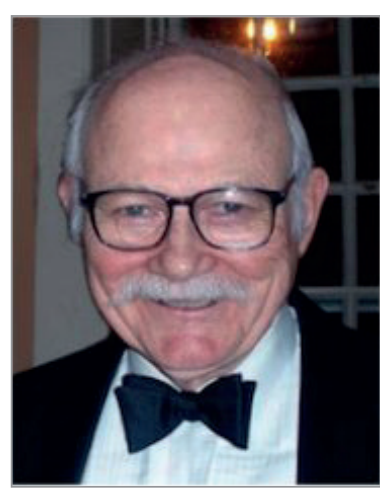

Ralph B. Potter https://goo.gl/PrSpfs Gadamer debate (Chris-

tians, 1989). His purpose was to overcome ethical relativism on the basis of a universal solidarity "grounded in our being as humans" (Christians, 1989, p. 18).

3. External circumstances, of course, like the use of force or fear, can make someone act according to a moral principle he would be ready to violate. As Aristotle remarked, although in another context, in these circumstances the moral principle seems to have the power of a physical law and an action looks very similar to any other worldly event.

4. In the original "visée éthique". The concept "visée", in the context of philosophical phenomenology points out the act by which conscience intents an object (intentionality). In this case, ethical intentionality refers to the need to solve the moral dilemma within the moral conscience (Ricoeur, 1991, pp. 266 and ff.)

\section{References}

Aristotle (1985). Ética a Nicómaco. Madrid: Centro de Estudios Constitucionales.

http://biblio3.url.edu.gt/Libros/2011/eti_no.pdf

Bennett, W. Lance; Lawrence, Regina G.; Livingstone, Steven (2007). When the press fails: Political power and the news media from Iraq to Katrina. Chicago: University of Chicago Press. ISBN: 9780226042862
Butler, Judith (2004). Precarious life: The powers of mourning and violence. New York: Verso. ISBN: 1844670058 http://www.wkv-stuttgart.de/uploads/media/butler-judithprecarious-life.pdf

Christians, Clifford (1989). "Ethical theory in a global setting". In: Cooper, Tomas W.; Christians, Clifford; Plude, Frances-Forde; White, Robert A. (eds.). Communication ethics and global change. New York: Longman, pp. 3-19. ISBN: 978 0801302244

Christians, Clifford; Rotzoll, Kim; Fackler, Mark; McKee, Kathy B.; Woods, Robert H. (2005). Media ethics: cases and moral reasoning. New York: Longman. ISBN: 978 0205418459

Gadamer, Hans-Georg (2004). Truth and method ( $2^{\text {nd }}$ ed.). London and New York: Continuum. ISBN: 9780826476975

Habermas, Jürgen (2014). Obras escolhidas. Ética do discurso, v. 3. Lisboa: Ed. 70. ISBN: 9789724415826

Husserl, Edmund (1954). Die Krisis der Europäischen wissenschaften und die transzendentale phänomenologie. Den Haag: Martinus Nijhoff.

Jordan, Eason (2003). "The news we kept to ourselves". The New York times, April 11.

http://www.nytimes.com/2003/04/11/opinion/the-newswe-kept-to-ourselves.html

Kant, Immanuel (1998). "Über ein vermeintes Recht aus Menschenliebe zu lügen”. In: Kants werke (hrsg. von Wilhelm Weischedel), Band IV. Darmstadt: Wissenschafliche Gesellschaft.

Libois, Boris (1994). Éthique de l'information: Essai sur la déontologie journalistique. Bruxelles: Université de Bruxelles. ISBN: 2800410884

Ricoeur, Paul (1991). Lectures 1: autour du politique. Paris: Seuil. ISBN: 9782020364881

Steele, Bob (2003). "The secrets we keep". Poynter: A global leader in journalism, April 16.

http://www.poynter.org/2003/the-secrets-he-kept/10022

Zelizer, Barbie (2010). About to die: How news images move the public. Oxford \& New York: Oxford University Press. ISBN: 9780199779987 